\title{
DON FORBES, VULTURE NEST FINDER, AND ERNEST FORBES, WING-TAG READER
}

\section{STUART HOUSTON, 863 University Drive, Saskatoon, Sask S7N 0J8}

Don Forbes and his son Ernest have made exceptional contributions to our Turkey Vulture Tracking Project.

Nest Finding by Don Forbes: In 2005, Don checked 20 deserted houses in the Porcupine Plain area, west to Chelan and south to Kelvington. Some log houses were almost invisible in the overgrowth of caraganas and poplars around long-deserted farmsteads that Don remembered from the past. To his and everyone's amazement, four deserted houses in that relatively small area contained active vulture nests. Stuart Houston and his crew arrived in early August to place alphanumeric wing tags (e.g. A22) on the young vultures when they were seven to eight weeks of age, just before they were ready to fly.

In his second year, 2006, this quiet, modest member of Nature Saskatchewan, with his friend Bernard Hayunga, visited 42 deserted buildings. That year and the next, Don found an unprecedented eight active successful vulture nests, including one each in a bunkhouse and a granary, more than anyone else reported in North America. In 2008, without increasing the size of the area, Don found ten active vulture nests which produced 19 young. Since then, deserted houses abandoned by vultures have been replaced by new sites, some found in company with Cliff Logan. A record 11 buildings were used by vultures in 2011. One building, reported to us initially by Brian Shuya, has raised vulture young for nine consecutive years. Another building has produced young during eight consecutive years and three other deserted houses for seven years. Three deserted houses were occupied only once. In total, 70 of Don's vulture nest attempts over eight years have produced a remarkable 128 young, eight of which fledged without wing tags.

Elsewhere in central Saskatchewan, nest finders have been spurred on by the example of Don Forbes. Finders of multiple vulture nest houses, from west to east, have been Doris Forsyth near Edam; Orval and Bev Beland widely around Cater and Medstead; Herman Thiessen near Debden; and Joe Graumans and Hank Donkers near White Fox. While traveling to inspect or tag at active vulture nests, Marten Stoffel, Harold Fisher and Mike Blom also add numbers of new nest sites each year.

For vultures, the term "nest" is a bit misleading. In fact, they don't build a nest as other bird species do. Vultures simply lay two eggs, two or three days apart, on dirt, hardwood, plywood, linoleum, or cement, in a somewhat darkened attic, clothes closet or basement of a deserted farm home.

\section{Tag Sighting by Ernest Forbes:}

Tagging vultures bears fruit when someone reports a wing tag at a different time or place. From 2008 to 2011, Ernest Forbes established a very different vulture record. On 11 occasions over 4 years, 2008 to 2011, Ernest read the numbers of 11 vulture wing-tags, tops for North America. While hauling waste to the Provincial Park sewage lagoon for L.A. Septic, Ernest noted an average of 30 vultures present on a sunny day; a few times 
each summer one vulture would have a readable wing tag. Up to three such sightings yearly included eight birds that had been raised in five different vulture nests within 5 to $19 \mathrm{~km}$ from the sewage lagoon, and another raised $252 \mathrm{~km}$ distant near Big Shell Resort (Table 1). Not a single vulture returned to the sewage lagoon when only one year old. We estimate that fewer than half the tagged vultures, after most of them winter in Venezuela, return all the way north to Saskatchewan when one year old. Five tags were read by Ernest at 2 years, two at 3 years, three at 4 years, and one at 5 years. Ernest read T37, tagged $14.2 \mathrm{~km}$ from the sewage lagoon, three times, 3, 4 and 5 years after it had been tagged as a nestling. It has now reached breeding age and we hope it will take up residence in one of our known buildings.

Unlike Ernest Forbes, the great majority of observers have each read or photographed a wing tag on a single vulture, -- but these add up, even though fewer than one vulture in a thousand in Saskatchewan carries a wing tag. We have now had several hundred sightings from the 927 Turkey Vultures tagged, 2003-2012 inclusive.

Recoveries/Encounters after leaving Porcupine Plain: In addition to Ernest Forbes' 11 sightings at the sewage lagoon, five other tagged vultures from the Porcupine Plain area have been sighted or photographed later. One nestling was found dead on a road only $16 \mathrm{~km}$ from its nest on its first migration south. Four more distant sightings or photographs of Porcupine Plain area birds have been from near the Highway 312 bridge east of Rosthern at 3 years; two in South Dakota at Akaska and Selby at 1 year; and near Young, Saskatchewan at 3 years.

Author's note: A tragic postscript ends this account. While returning on Highway 38 from an art class in Kelvington, Ernest Forbes died at 9.30 pm on 7 August 2012 following a fatal collision with an Elk. Marten Stoffel and Stuart and Mary Houston represented Nature Saskatchewan at Ernest's funeral in Porcupine Plain on 14 August 2012.

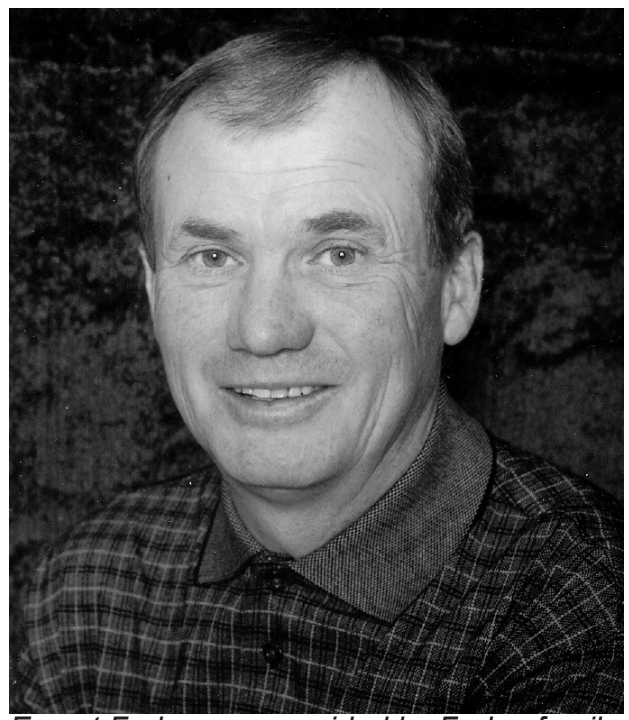

Ernest Forbes - provided by Forbesfamily 
Table 1. - Sightings of vulture tags

\begin{tabular}{|c|c|c|c|c|c|}
\hline \multicolumn{6}{|c|}{ ERNEST FORBES SIGHTINGS (11) AT GREENWATER SEWAGE LAGOON } \\
\hline TAG & date tagged & where tagged & date sighted & distance $(\mathrm{km})$ & \# yrs \\
\hline T13 & 1Aug06 & Big Shell & 19Jul08 & 252.3 & 2 \\
\hline \multirow{3}{*}{ T37 } & 4Aug06 & Chelan S & 7Jul09 & 14.2 & 3 \\
\hline & & " & 20 Sep10 & 14.2 & 4 \\
\hline & & " & 2Jul11 & 14.2 & 5 \\
\hline T40 & 4Aug06 & Kinloch N & 14Jul10 & 8.8 & 4 \\
\hline T41 & 4Aug06 & bunkhouse & 17Aug08 & 8.8 & 2 \\
\hline A20 & 2Aug07 & Kelvington E & 12Jul09 & 19.1 & 2 \\
\hline A22 & 2Aug07 & Kinloch N & 16Jun09 & 6.9 & 3 \\
\hline A24 & 2Aug07 & Greenwater & 24Jun11 & 6.5 & 4 \\
\hline B29 & 6Aug08 & Greenwater & 16Jun10 & 6.5 & 2 \\
\hline S61 & 12Aug09 & Kelvington E & 2Jul11 & 15.1 & 2 \\
\hline Maxir & $\mathrm{n} 30$ to 50 & es 24 June 2 & & & \\
\hline
\end{tabular}

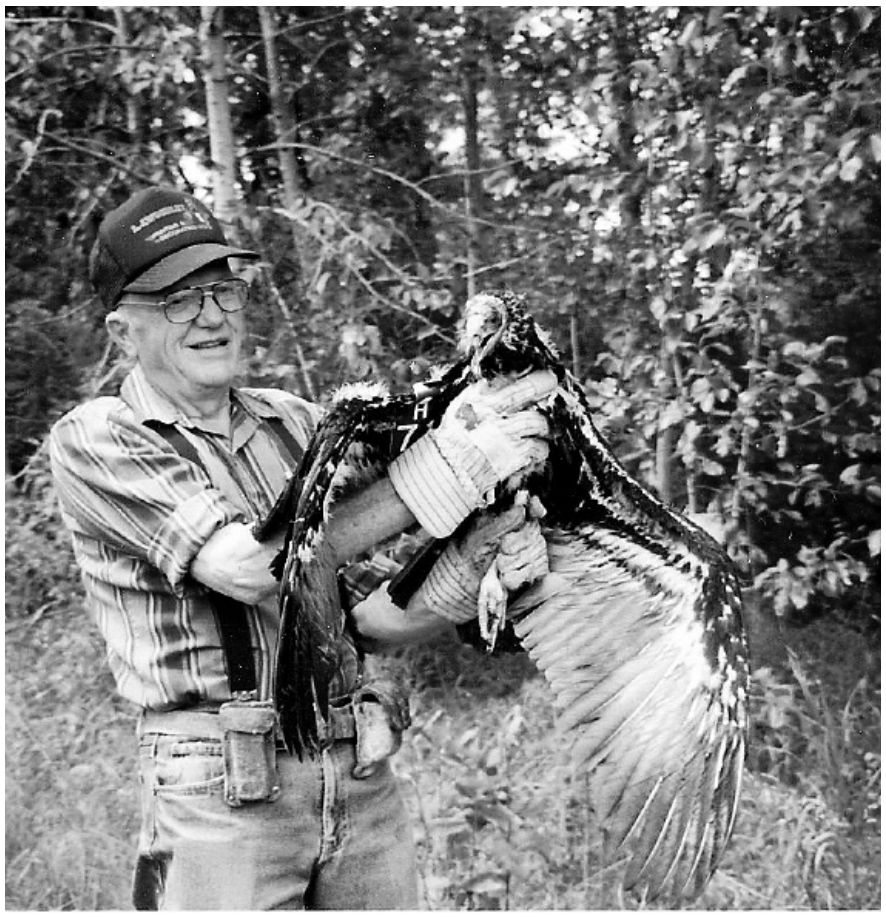

Don Forbes with Turkey Vulture

- Brent Terry

70 (4) December 2012 